\title{
INTRODUCTION OF VERNACULAR ARCHITECTURE STUDIES AT THE FACULTY OF ARCHITECTURE IN BELGRADE
}

The paper examines the work of Aleksandar Deroko at the the University of Belgrade's Faculty of Architecture and the inclusion of his rich personal knowledge about the vernacular architecture in the study programme, which he gained from long-term field research. As an assistant professor, he introduced the interpretation of vernacular architecture in the course on Byzantine and Old Serbian Architecture in 1929. After the study programme reform in 1935, a new course - named Old Serbian Architecture - was established, with one semester dedicated to the medieval monumental architecture and the second to rural and urban houses. In 1945/46 academic year, the course was renamed Vernacular Architecture and it incorporated medieval and vernacular architecture of the former Yugoslavia. Practical assignments dealt more with vernacular architecture and, through them the student's discovered the fundamental principles and methods of the vernacular construction. The goal of the studies was for students to comprehend and adopt basic traditional canons of construction and apply them to their own projects of cooperative centres, countryside schools, monasteries, etc. Through illustrations the paper will present, till now unpublished, student projects from the archives of Belgrade's the Faculty of Architecture's office for the architectural heritage of Serbia.

\section{Mirjana Roter-Blagojević}

University of Belgrade - Faculty of Architecture

roterm@arh.bg.ac.rs

KEY WORDS

Marko Nikolić

University of Belgrade - Faculty of Architecture

ALEKSANDAR DEROKO

marko@arh.bg.ac.rs

TRADITION

VERNACULAR ARCHITECTURE

EDUCATION

STUDENTS' PROJECTS 


\section{INTRODUCTION}

Although Aleksandar Deroko began his studies in mechanical engineering at the Faculty of Technical Sciences in Belgrade ${ }^{1}$ as a result of his love for airplanes $^{2}$ the beginning of the war interrupted his education and he became a war pilot. ${ }^{3}$ Due to an illness, he was demobilised before the very end of the war in 1918 so he continued his studies first at the Royal Engineering School in Rome, and then in Prague and Brno. ${ }^{4}$ Upon his return to Belgrade, he chose to

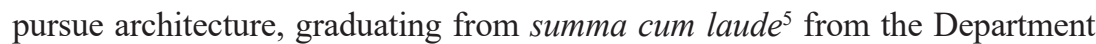
of Architecture of the Faculty of Technical Sciences at the age of 32. The fact that he published his first paper Tri manastira srednjovekovnog Rasa (Three Monasteries of Medieval Ras) in 1922 in a magazine Misao, tells us that during his studies he already focused on research of medieval architectural heritage. The topic of his graduation thesis was The Church of St. Sava and it served as the basis of the work he submitted in a competition for architectural design solution of the church, which won him first place, but also for a project he did with the award runner-up Bogdan Nestorović at the later stage. ${ }^{6}$ It certainly influenced his admission to the position of a teaching fellow on the course of Byzantine and Old Serbian Architecture ${ }^{7}$ right after his graduation.

Professor Gabriele Millet, one of the most famous Byzantologists at that time and an extraordinary connoisseur of the Balkan medieval heritage ${ }^{8}$ had a particularly strong influence on Deroko and his work in the field of the history of architecture and research of architectural heritage. Deroko had one semester of a training course with Millet at Ecole des Hautes Etudes. ${ }^{9}$ His companionship with Parisian avant-garde artists also played a significant role, while his close friendship with writer and poet Rastko Petrović with whom he travelled the countryside, visiting churches, monasteries and settlements in the areas of Stari Ras, Skadar, Kosovo and Lim, and the Montenegrin coastline, closely familiarising himself with vernacular tradition left a profound mark on him. ${ }^{10}$ On these travels, he collected endless notes and drawings which he would use in his future books and through which he would touch the hearts of his students and readers through his distinctive drawings of dynamic lines with hand-written comments. ${ }^{11}$

THE INTRODUCTION OF ARCHITECTURAL HERITAGE STUDIES IN SERBIA

\section{Period Leading Up to the World War I}

Mihailo Valtrović1 ${ }^{12}$, who was professor of the Theory of Construction on Dry Land course in 1875, the only specialised course in the field of building construction within the general programme for technical professions ${ }^{13}$, is 
credited with establishing and enriching architectural studies at the Faculty of Technical Sciences of Belgrade College School. Those wishing to further educate themselves in the field of architecture had to study abroad, mainly at German schools in Berlin, Aachen, Munich, Karlsruhe, usually at the expense of the state. Even Valtrović himself studied schools in Germany, and included the development of buidlings bluprints, civil structures and stylistic forms in his course. The graduation thesis on the Church of St. Sava in 1879, signed by Valtrović, included the design of a new building, in this case a semi-gymnasium with the use of traditional materials, stone and bricks, and in currently used Renaissance style. ${ }^{14}$ This affirms that design of academic, historical styles prevailed in the studies after the practice of central European schools of that time.

When Valtrović transferred to the Faculty of Philosophy of the Belgrade College School and founded the Department of Archaeology in 1882, where research about general and national history of art and architecture started, studies at the Faculty of Technical Sciences were taken over by Dragutin Milutinović. ${ }^{15}$ He was his friend from student years in Germany and his colleague on long-term field work on recording the remains of medieval architecture. He greatly expanded the architectural studies, with students of technical sciences graduating with a better professional skillset in general and specialised architecture, including building structures, statics, and projects of public and private buildings and the theory of styles. ${ }^{16}$ Milutinović lectured these comprehensive studies by himself and was joined by Andra Stevanović17, who was appointed for a new course on Theory of Building Structure ${ }^{18}$ in 1890. Studies in architecture gradually started to branch out into divisions for architecture, descriptive geometry and drawing skills. ${ }^{19}$ This, of course, was insufficient for the complete education of future architects; therefore their specialisation in the fields of perspective, construction stylistics, building design, ornamental drawing and Byzantine style ${ }^{20}$ in the third and fourth year of studies was proposed but it was not implemented straight away. Nevertheless, a new law reformed the Faculty of Technical Sciences in 1897 with the introduction of three departments: the Civil Engineering, Architectural and the Mechanical-Technical departments. ${ }^{21}$ New specialised architectural courses were introduced based on the practice of central European schools, particularly on German higher technical schools, polytechnical schools, from which architects of that time working at the Faculty of Technical Sciences graduated from. Students received complete educational programmes necessary to start their own business in architecture with the inclusion of 11 new specialised courses, so there was no need for future generations to get additional education abroad..$^{22}$ It is important to stress that History of Art and Byzantine Style with practical assignments ${ }^{23}$ was included in these studies. 
At the turn of the century, after Milutinović's sudden death, Stevanović, a connosseiur of vernacular architectural tradition, who researched the Byzantinestyle church architecture in Kosovo, ${ }^{24}$ was supposed to take over teaching of the course on Byzantine Syle with the Church Design..$^{25}$ A part-time Professor Nikola Nestorović ${ }^{26}$ temporarily taught the course until $1903^{27}$ when Milorad Ruvidić $^{28}$ was appointed a professor. Valtrović and Milutinović's efforts to artistically enrich the architectural studies and research on national architectural heritage were rewarded with the inception of Department for the History of Architecture with Byzantine style. ${ }^{29}$ When the Belgrade College School became the University of Belgrade in 1905, students of the Department of Architecture studied 38 courses, among them History of Art, History of Architecture, Theory of Styles and Byzantine Architecture. A graduate thesis had to be from the field of the design of public buildings and Byzantine architecture. ${ }^{30}$

It is obvious that Byzantine Architecture fought its way to the studies of future architects and to obtain an equal place with neoclassical academic design. This is probably what brought about the Vienna Secession and Munich Jugend style in the design of private buildings prior to the WWI, influenced by contemporary aspiration in architecture and desire to break off with historicism and create a new age architecture in Serbia. Also, these were initial attemtps to expand the use of decorative forms of medieval sacral architecture both of general Byzantine and indigenous Morava school not just in church buildings but also profane. ${ }^{31}$ This was the beginning of the so-called Serbo-Byzantine school, which opposed international neoclassical academic styles. Among these achievements, extremely rare in state public buildings is the district centre (Načelstvo) in Vranje erected in 1908, which stands out with richly ornamented façade reflecting medieval Morava school with a row of stone blocks and three rows of bricks. It also reflects decorative elements characteristical of the Morava school churches, such as rosettes, stylised interlaced ornaments around the windows, and the like. An engineer within the Ministry of Construction Petar Pera Popović, ${ }^{32}$ who designed it, worked at the same time on the reconstruction of the Lazarica church from the fourteenth century in Kruševac built by Prince Lazar in his capital. Along with the church of Ravanica Monastery, the second prince's endowment and the future mausoleum, it was built before the Battle of Kosovo, when the Prince was killed and Serbia became a vassal state of the Ottoman Empire..$^{33}$ They mark the beginning of emulation of the church type from the Holy Mountain and the development of a new indigenious style in church design which was different from that of Byzantine. They were models in later reconstruction of national style, and they also had a strong patriotic connotation. 


\section{Interwar period}

With his work on the reconstruction of medieval churches and his dedication to applying their design elements to modern buildings, Popović drew attention to himself and proved to be the right fit for a professor to explicate the principles and forms of Byzantine architecture ${ }^{34}$ to students after these studies were renewed in 1919. After the 1922 reform, the Architectural Department had seven sub-divisions, one of which was Architectonics, with the History of Art and Vernacular Architecture and Arts. ${ }^{35}$ Students successfully transposed their knowledge of the national architectural tradition into modern designs of sacral and public buildings designed for graduate thesis, ${ }^{36}$ but also in practice where elements of the medieval national tradition were introduced on the academically-based spatial structures and façade compositions through their stylistic and decorative design.

As of the 1925/26 academic year, the university students were recruited as teaching staff, and among them was Deroko who was appointed as an assistant volunteer of the Byzantine Architecture ${ }^{37}$ course, having already cooperated with Professor Popović on a church construction. ${ }^{38}$ Education at Belgrade's Faculty of Architecture with its excellent professors, combined with a professional development in Paris with Millet, and his passionate personal recording of traces of traditional building, all created a good basis for Deroko's further training when he became an Assistant Professor after 1929. ${ }^{39}$ He became the Head of the Department of Byzantine Architecture in 1930, and welcomed a young associate, an architect Grigory Samoilov, ${ }^{40}$ who became an assistant volunteer for Byzantine Architecture in 1932. ${ }^{41}$

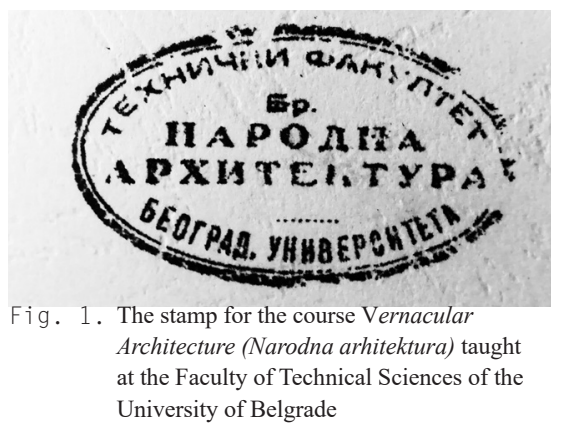

Fig. 2. The photo of Professor Aleksandar Deroko at the moment of retirement with his signed dedication, and his stamp - today in the teachers' office for Architectural Heritage at the Faculty of Architecture, University of Belgrade

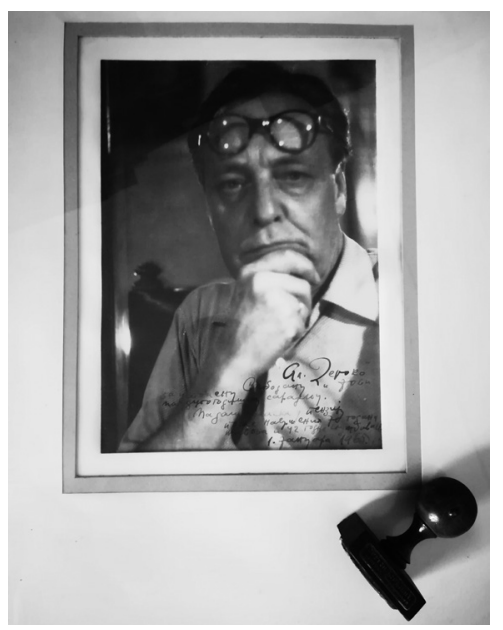


It is significant that during the 1930s, Byzantine Architecture was dropped from the name of the course and this department. The Institute of Vernacular Architecture was founded and its acting director was Deroko ${ }^{42}$ with professors Branko Tanazević ${ }^{43}$ and Branko Popović ${ }^{44}$ as its members. After the adoption of the new Decree of the Faculty of Technical Sciences in 1935, the Department of Vernacular Architecture was introduced, and certain changes were made to the architectural studies. There was a course on Vernacular Architecture in VII and VIII semester, which comprised three hours of lectures and three hours of practical assignments, taught by Deroko, who was an Associate Professor at the time. ${ }^{45}$ (Fig. 1) He can certainly be credited with making substantial improvements to studies related to the research on national architectural heritage. From that time apart from monumental medieval architecture concentrated on the study of sacral buildings, the studies of traditional vernacular architecture were also introduced in the program. This was necessary for future architects because the so-called folklore style was expressed in the works of architects of that time, especially by his colleague Branislav Kojić. ${ }^{46}$

\section{Period of the second half of the twentieth century}

After the World War II, autonomous Faculty of Architecture emerged in 1948. ${ }^{47}$ The curriculum relied on the pre-war structure of courses, but with changes made in the field of modern design it gradually oriented exclusively towards architectural design and the application of new structures and materials. During the war, its staff shrank greatly with only 10 professors and two assistants from the pre-war period. Professor Aleksandar Deroko, Assistant Professor Djurdje Bošković and a teaching fellow Milivoje Tričković ${ }^{48}$ were in the Department of the History of Art and Architecture and they held the History of Art and History of Architecture courses according to the curriculum from 1946. The History of Art was taught in the second and the third year, with two hours in each semester. Deroko held the course in the first afterwar academic year of 194546, which was taken over by Bošković after this. The History of Architecture was taught throughout all four years of studies, starting with the ancient history, medieval age and modern history and vernacular architecture. The Ancient History Architecture was taught by Professor Bogdan Nestorović in 1945-48, along with the courses from his Department of Architectural Design, and it was taught by Deroko from 1948 to 1960. Nestorović also taught Modern History Architecture in the 1945/46 academic year and after it was taught by Tričković. The Medieval Age Architecture was taught by Bošković. ${ }^{49}$ 
In addition to the above mentioned courses, Deroko, as in the prewar period, held the course on Vernacular Architecture which was taught in the fourth year, in the VIII semester with four hours of lectures and four hours of practical assignments, a huge teaching load. ${ }^{50}$ The course comprised of studies of architecture from the territory of entire Yugoslavia, both medieval sacral and vernacular. There were no graduation thesis in this course as a consequence of the withdrawal of historic architecture and church buildings from design practice of that time. However, students devised projects on country schools, cooperative centres, monastery complexes, and the like, which were designed in the style of traditional architecture..$^{51}$

The trend of gradual decrease in studies of history of architecture was visible in 1949 when, according to the new curriculum, these studies were extended to five years, but the History of Architecture was taught only in two semesters in the second and the third year, through four hours of lectures and practical assignments. ${ }^{52}$ This tendency was present in the curriculum from 1956 when the course was still taught in the second and third year, but only with two hours of lectures in both semesters, without practical assignments. However, a new independent course the History of Architecture of People of FPRY was introduced in the third year with two hours of lectures per semester and two i.e. four hours of practical assignments. ${ }^{53}$

In 1958 there were minor reforms when the History of Architecture - Ancient History, Medieval Age and Modern History was introduced in the II semester of the second year and in the I and III semester of the third year with two-hour lectures, but a course on History of Contemporary Architecture with two hours of lecture was also introduced in the forth year. The course on Architecture of People of FPRY was held in the last fourth year, in both semesters with two hours of lectures and practical assignments. ${ }^{54}$ This demonstrates that, probably due to professor Deroko's enormous reputation, the studies of national architectural heritage held a significant place in the study programme and that in addition to ex-cathedra lectures, there were practical assignments in which students familiarised themselves through drawing with the principles and forms of traditional architecture.

Nevertheless, major reforms in the organisation of studies at the Faculty of Architecture came into force in 1963 since it was believed that the studies should meet demand, resulting in the introduction of division in education into two levels. The first cycle was general for all students and it lasted for five semesters, after which they would receive professional title Architectural 
Engineer. There were lectures in general History of Architecture - Ancient History, Medieval Age and Modern History within these general studies. The second cycle, lasting four semesters, had two courses on architectural and structural design. With the old name, Vernacular Architecture was only held at the Department of Architectural Design in the final year, and only with two hours of lectures in a semester. ${ }^{55}$ This halved the teaching load, and the withdrawal of practical assignments was irreplaceable because the students lost the possibility of familiarising themselves with the architectural tradition through practical work. Soon after, on 1 January 1965, Professor Deroko retired after 42 years of work. ${ }^{56}$ (Fig. 2)

Soon, it turned out that the education in cycles neither met the demands of the society since the economy did not require experts with only the first cycle education, nor the wishes of students, who mainly continued their studies to the second cycle. Also, the division of experts to explicitly specialised designers and constructors did not correspond to architectural practice which required a complete professional capability of synthesising both fields. In order to overcome this, the studies were re-established in general programme lasting four years and one additional semester for graduation thesis already in 1966. The Vernacular Architecture was taught in the third year with only two hour ex-cathedra lectures, under the guidance of an Associate Professor, Slobodan Nenadović. ${ }^{57}$ In the first semester, it consisted of studies of medieval, reneissance, baroque and Islamic architecture of Yugoslavia, while in the next semester medieval towns, rural and urban architecture were explored. ${ }^{58}$

This programme lasted until 1969/70 when a new effort was made to modernise the studies so a board of young professors created a new curriculum, the socalled New School. It started in the 1971/72 academic year, but it was shortlived and lasted only until 1973/74. ${ }^{59}$ The position of studies of history of national architecture in the third year did not change until the reforms in 2005, so it was taught in almost the same structure in two semesters, with two hours of the so-called monumental architecture in the winter semester and only one hour of vernacular architecture in the summer semester through ex-cathedra lectures. Due to political changes and the dissolution of Yugoslavia, the name of the course was changed, with the Architecture of the Past in Yugoslavia becoming the History of Architecture and Settlements in Serbia and Montenegro i.e. Serbia. The content of the course was partially condensed, although sacral medieval and vernacular architecture were still being explored in a wider context than within the state borders. ${ }^{60}$ 
A large and precious collection of practical assignment sheets, which are kept in the teachers' office archives, testifies to several-decades long commitment and efforts of students to research and architectural tradition through direct work and field recording, a method nurtured by Professor Deroko and carried on by his students and successors alike. ${ }^{61}$

\section{REVIEW OF STUDENTS' PROJECTS}

A part of students' practical assignments in the Vernacular Architecture course has been preserved in the teachers' office at the Faculty of Architecture, where professor Deroko spent his career, and this paper reviewed the projects of 1953/54 and 1954/55 classes. There are some renowned names among them, such as: Zoran Petrović, an architect who later reached all academic ranks, from a teaching fellow to a full-time professor of the Faculty of Architecture, ${ }^{62}$ and during his teaching career he was also a vice-dean and a dean; Vladimir Tvrtković, an architect, later a teaching fellow and a professor of the faculty; ${ }^{63}$ Mihailo Čanak. ${ }^{64}$ The works represent projects of contemporary architectural facilities in which the principles and elements of traditional vernacular architecture were applied.

Students' design proposals consist of ground floor plans, upper floor plans, roof plans, vertical sections, layouts and axonomentric previews. Students' ability to draw was particularly developed. They used graphite and colour pencils, watercolour tubes and pigment colours. The use of colours is particularly stressed in the drawings of facades and axonomentric previews, which speaks about professor's desire to develop the sense for technical but also for artistic drawing in his students. It is obvious that the project of every house was placed in a context, i.e. that the houses were incorporated into their surroundings, often imaginary, but with all characteristics of a certain area for which the project was intended.

Most attachments to project concepts, which were given in a comparable scale, were placed on one sheet as it was common with construction projects of new interwar buildings, which had the scale of 1:200, plans of all floors, sections and layouts in 1:100 scale on one sheet, striving for the projects to be clear and self-explanatory. Students' desire for systematisation and the design of their works should be particularly accentuated, this being reflected in the writing of headlines, descriptions under drawings, and the like, where by the design of each individual letter, in different sizes depending on the information importance, they successfully navigated the difficulties of creating all project parts, which is nowadays greatly facilitated by the use of computers. 
Within the specific topics that the students worked on, special attention should be paid to individual projects of teachers' houses, schools, cooperative centres, as well as rural and urban national committee houses. Common to most of the works is that students designed new buildings on the principles of a traditional rural house with timber framing from Pomoravlje and a rammed earth house from Vojvodina, as well as an Ottoman type town house.

In the project of ground-floor country school of student Eremic Lazar, the spatial structure is contemporary, with entrance vestibule, a hall as a central area of the building, while both on the left and right there are classrooms, and there is a small office in the extension of vestibule. A characteristic traditional feature of a typical Moravian timber framed house is a corner porch where the hall is entered. The majority of preserved works are designed in the Ottoman town house style since the designed buidlings were intended for Kosovo and Metohija and central Serbia.

In two projects of teachers' houses in Kosovo and Metohija, students Milan Martić (Fig. 3) and Milan Janić (Figs. 4 and 5), followed the principles of traditional spatial organisation adapted to contemporary needs. Houses are entered from porches, where one enters a vestibule, as a central area of the house, and from there one climbs the stairs to the upper floor. Other spaces, rooms and a kitchen are centered around the vestibule. Above the ground floor porches, there are open or closed balconies and verandahs. Students used elements of tradition in their projects, which are reflected in the spatial organisation of houses, the application of a structural assembly, and the use of traditional materials. Through projects, students have adapted the traditional house to contemporary needs with the introduction of a number of different rooms according to their purpose and size, the introduction of a sanitary unit, a special part with a kitchen and a storage. In the outer design, they sought to maintain the traditional look of the house with a "bondruk" system.

In the projects of rural and urban national committes houses, the plans are more complex, but they follow the central blueprint of a town house of Ottoman type. Most often these are houses which have the ground and the upper floor, with central vestibules around which offices are centered on the ground floor, as well as utility rooms, while on the upper floor, festive halls and offices are grouped around the main vestibule. The examples are as follows: a local national committee house in a village by a student Dragojlo Kutlašić (Fig. 6), a rural national committee house by a student Nikola Nešić (Fig. 7), a rural national committee centre by a student Vladimir Trrtković (Fig. 8), the building 


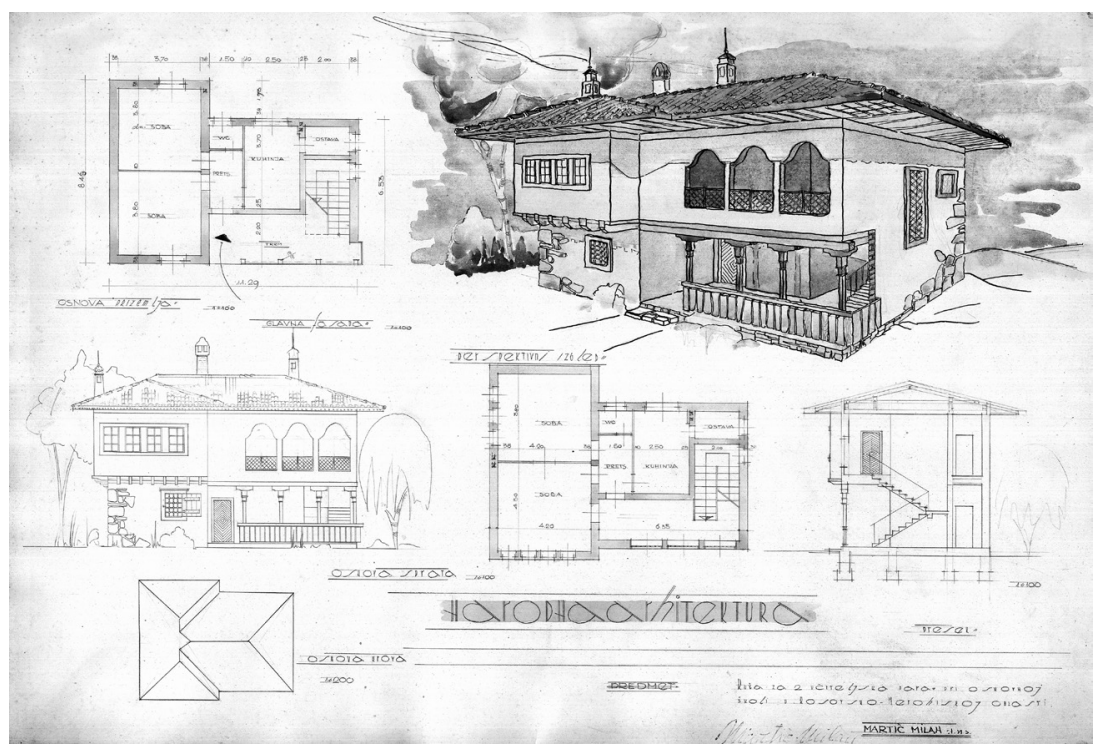

Fig. 3. Project for the teacher house in Kosmet - ground floor, first floor, vertical section, main facade and perspective view, student: Milan Martić

\section{HAPO IHA APXUTEKTYPA} "KYTA 3A YUUTEDE
JAHUT MUII CRMAH.
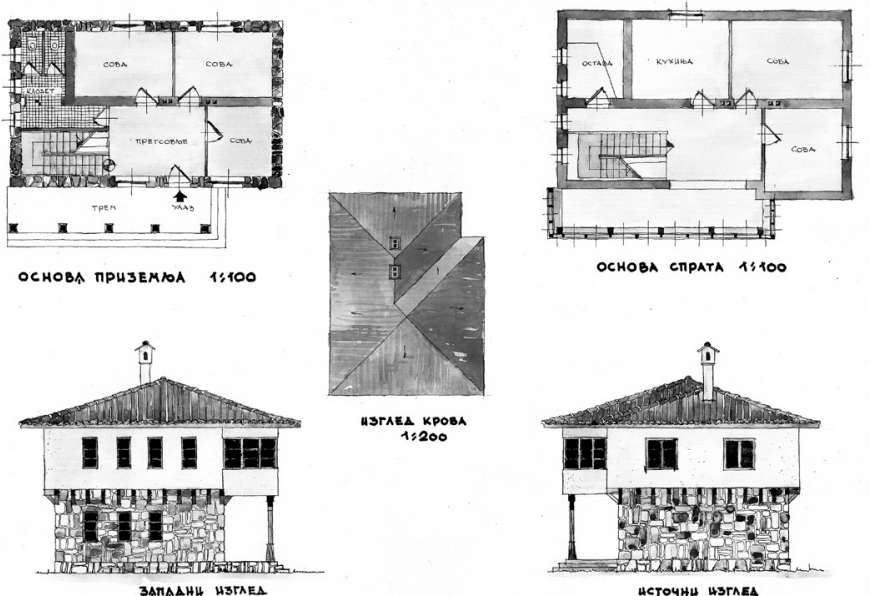

USTAEA KPOBA

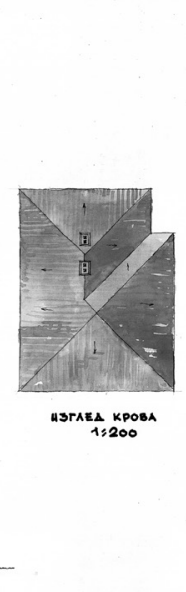

OCHOBA TPL3EMIOA $1: 100$

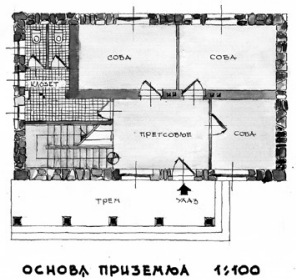

3ATASHLL HZTAEA

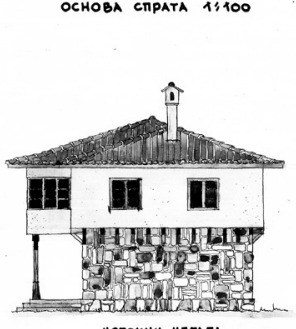

Fig. 4-5. Project for the teacher house in Kosmet -4) ground floor, first floor, roof base and the western and east facades, 5) perspective view, student: Milan Janić

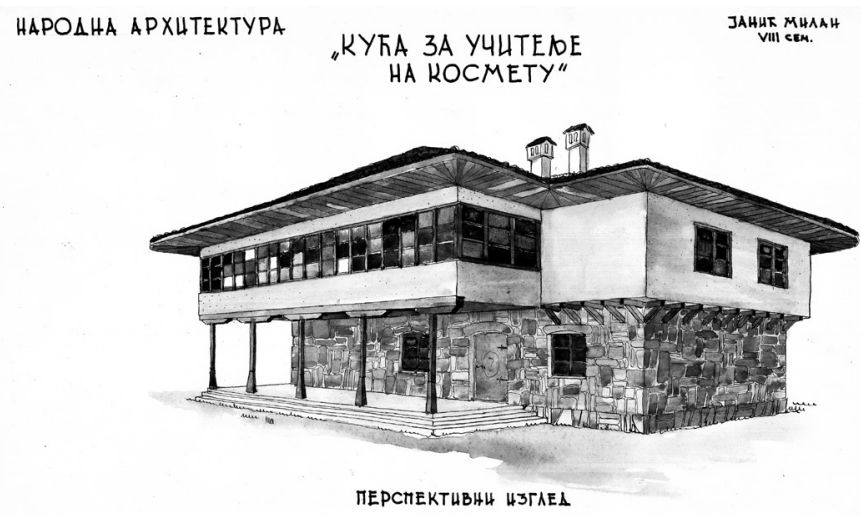


of municipal national committee by a student Milenković Dušan, the building of town national committee by a student Zoran Petrović (Fig. 9), buildings in Morava style by students Mihailo Čanak (Fig. 10), Milivoje Đukić and Jovan Zrnić (Fig. 11). In certain projects, as is the case in the project by the student Dragojlo Kutlašić, the main vestibule can have two altitudes, so at the upper floor a gallery with pillars is constructed. The obligatory architectural element is a porch on the ground floor, i.e. a balcony on the upper floor which was usually placed along the complete front façade. In some students' works, in addition to the porch, a separate sitting area, a verandah is envisaged which can be on the ground or upper floor.

Buildings inspired by Ottoman architecture have massive ground floor walls made of rustically shaped stone blocks, while the upper floor is usually jettied and is made of light skeletal timber framed construction with filling. The walls were treated with mortar on the outside, but in some parts or on the entire floor the wooden skeletal construction is visible, so it follows a contemporary principle of visibility of bearing construction on the façade. Additionally, the application of open porches with decorated wooden pillars along the ground floor, as well as balconies, verandahs and bay windows on the upper floor contributes to the traditional appearance of buildings. Deep eaves on mildly sloped roofs covered by pantile, above which richly ornamented chimnies are mounted, represent a distinct element. From precise design of these elements, it can be concluded that students possessed extraordinary knowledge of forms, tradition and value of vernacular architecture as demonstrated in their projects.

The works done in the style of Vojvodina ground rammed earth house were intended as houses for teachers. Students sought to literally observe the principles of Vojvodina rural house, related to spatial organisation, construction and design. In the project of a student Zoltan Peter (Fig. 12), a characteristic disposition of Vojvodina rural house was implemented, with narrow part of the house placed related to street line, along the sideway of a lot. The rooms of the house are longitudinally layered within one tract, with a central entrance room, a fireplace, a kitchen, and on the left and right there are other rooms, the biggest one directed toward the street as is the case with a typical rammed earth house. Along the courtyard façade, towards the courtyard, there is a long wooden canopy, as in the project of a student Janjatov Rade. In the project of a student Josip Svoboda (Fig. 13), two one-tract houses are interconnected by a canopy. One house is located along the street line, with narrow side toward the street and long side toward the courtyard, and the second house is placed parallel with it in the interior of the courtyard, with a garden, an orchard and 


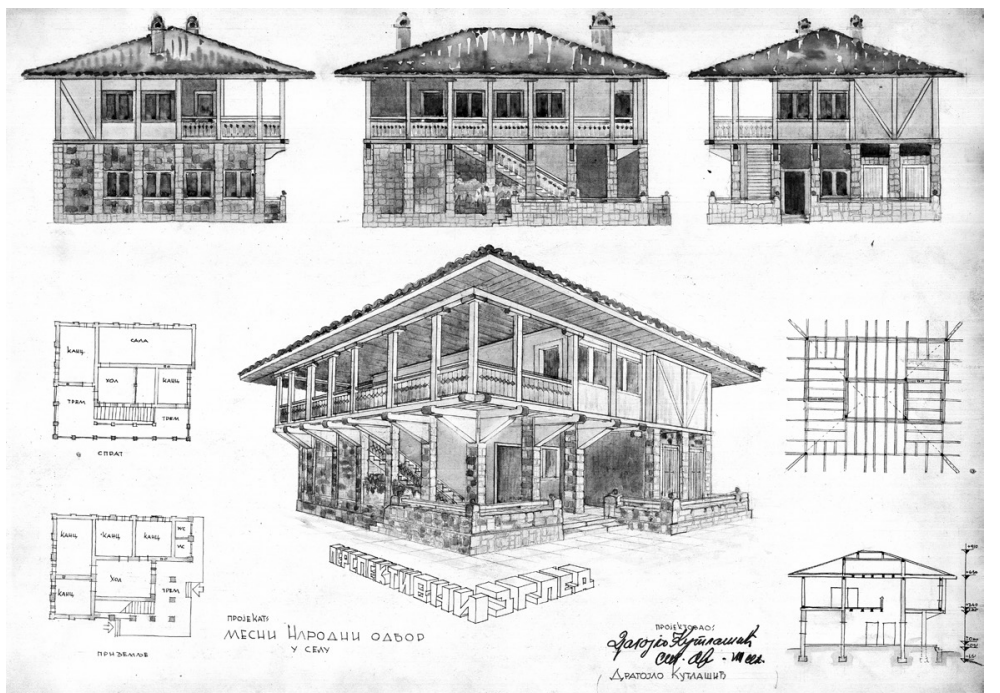

Fig. 6. Project for the local national committee house in a village - ground floor, first floor, roof base, vertical section, facades and perspective view, student: Dragojlo Kutlašić

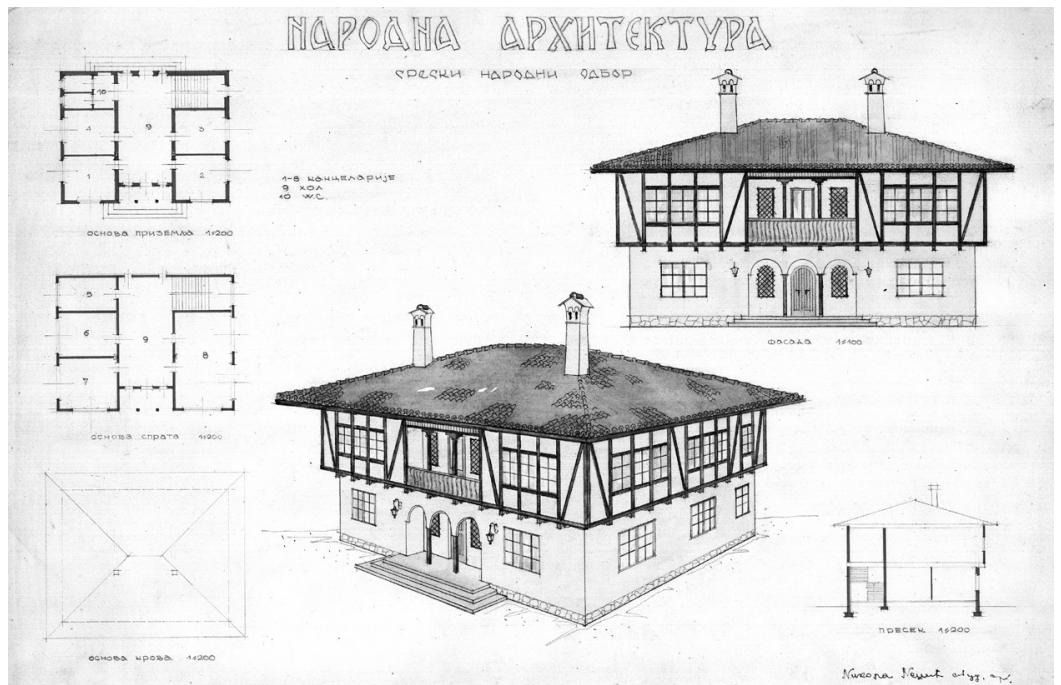

Fig. 7. Project for the rural national committee house - ground floor, first floor, roof base, vertical section, main facade and perspective view, student: Nikola Nešić

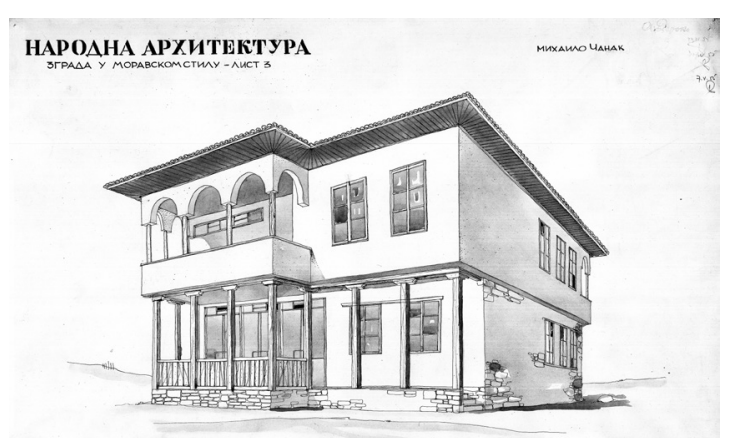

Fig. 8. Project for the rural national committee centre - ground floor, first floor, roof base, vertical section, main facade and perspective view, student: Vladimir Tvrtković 


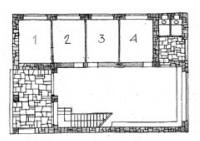

HHIADOAIHIA ANDYKHHIIEIKTYYIPA
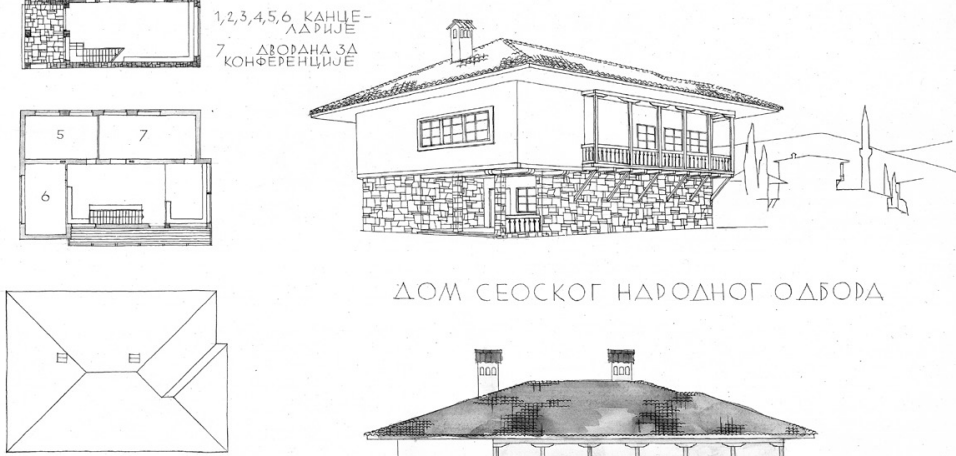

$\triangle O M$ CEOCKOT HADOAHOT OADODA
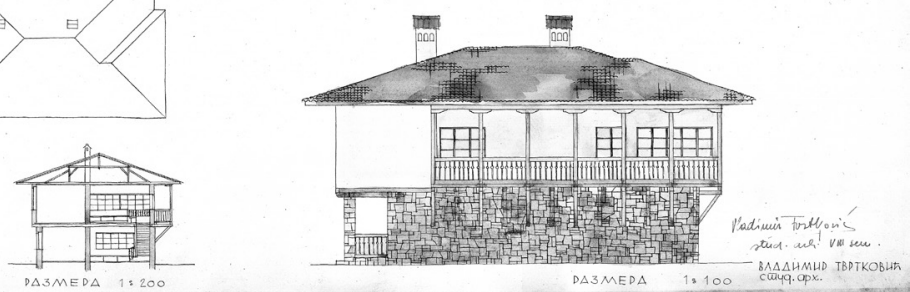

Fig. 9. Project for the building of town national committee - perspective view, student: Zoran Petrović

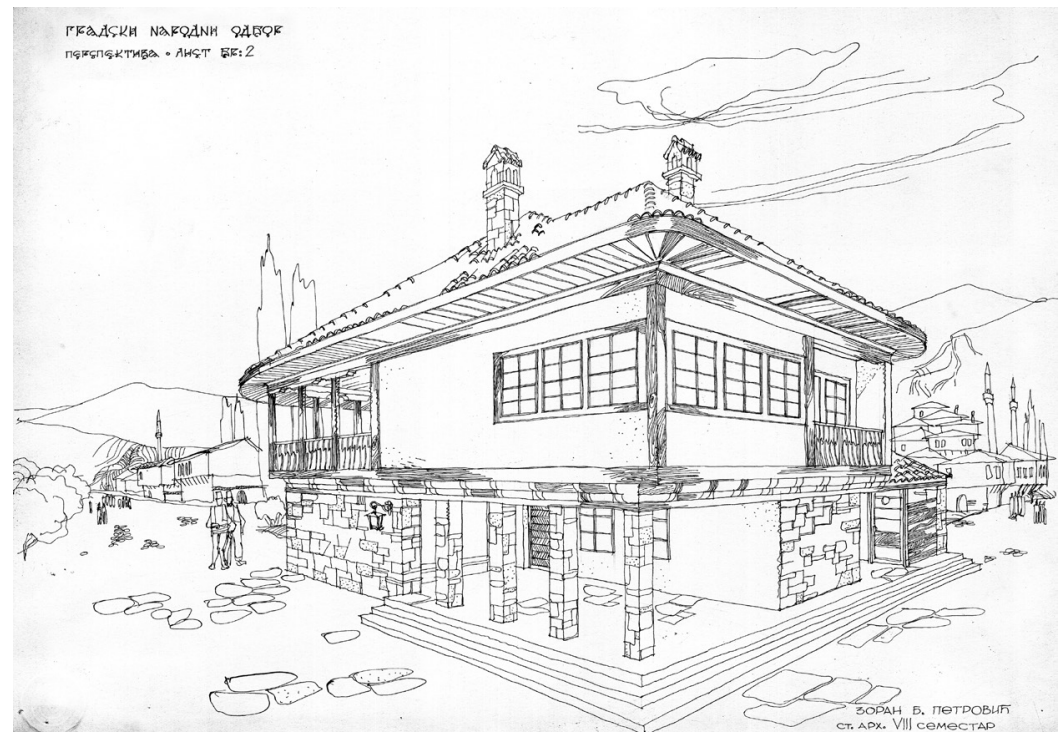

Fig. 10. Project for the building of town national committee - perspective view, student: Zoran Petrović

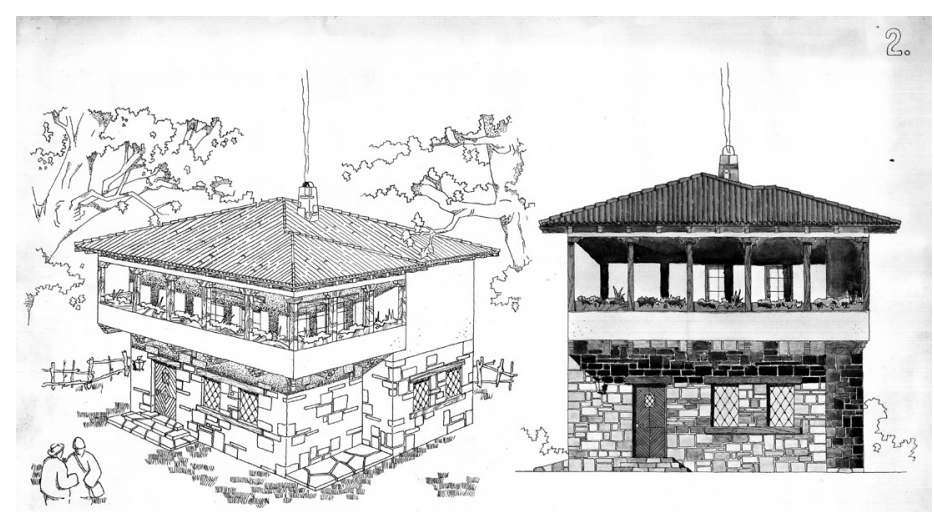




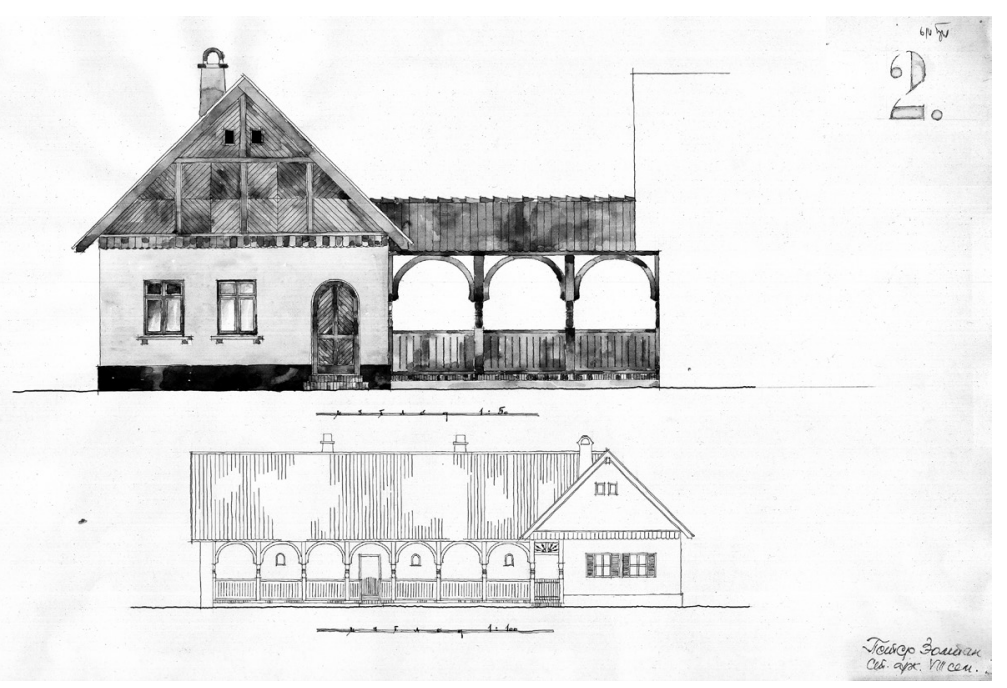

Fig. 12. Project for the teacher house in Vojvodina - street and courtyard facade, student: Zoltan Peter

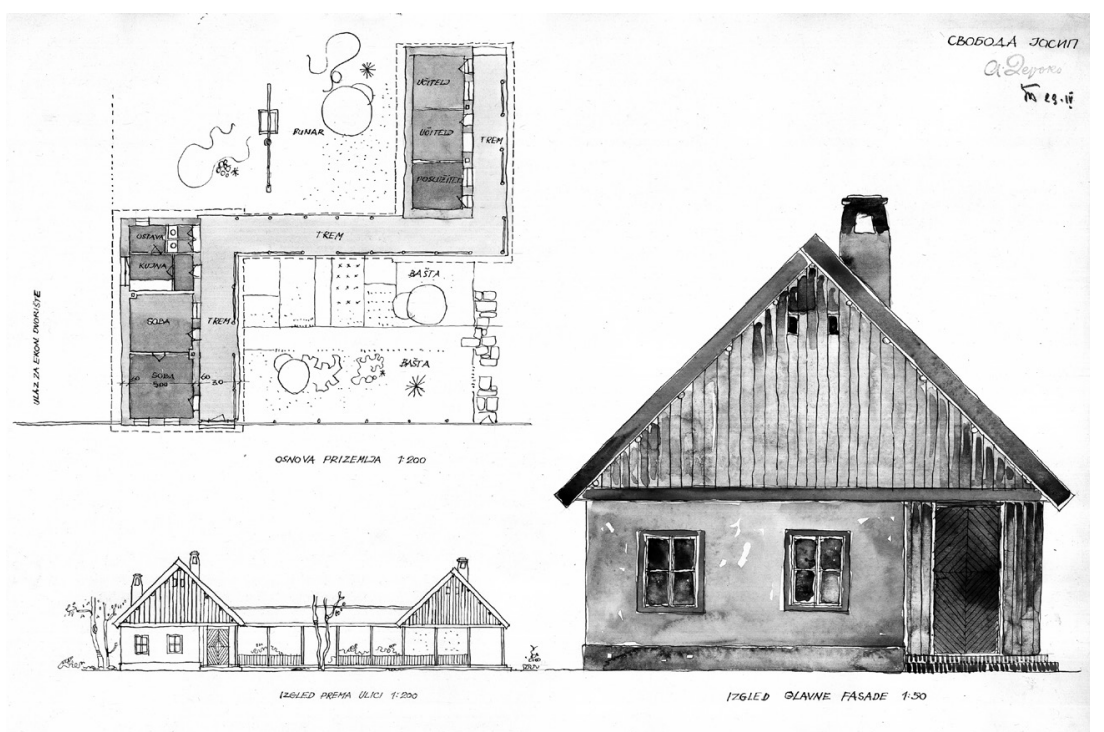

Fig. 13. Project for the teacher house in Vojvodina - ground floor, street and courtyard facades, student: Josip Svoboda

MAPORHA APXUTEKTYPA. УЧHTEMCKA KYTA Y BONBOXHHU

JAHETOB PAEA
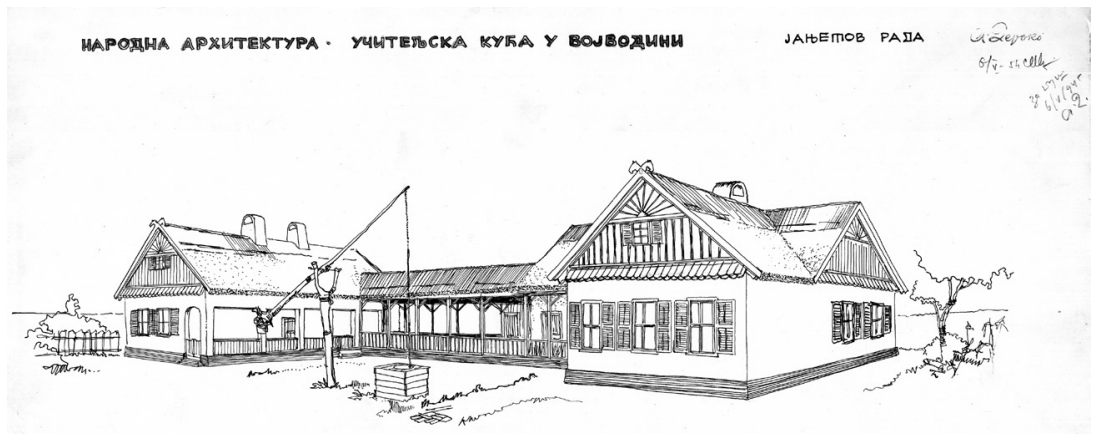

Fig. 14. Project for the teacher house in Vojvodina - perspective view, student: Rada Janjetov 
a well. In the house to the street there is a large apartment with two rooms, as well as a shared kitchen with a pantry and two toilets accesible from the porch. In the second house, there are three rooms for teachers and a server, accessible directly from the porch. The walls of the houses are massive, from rammed earth, and the canopies have wooden pillars, parapets and arches. In the design of outer street facades, the principles and elements of a traditional Vojvodina house were applied. They usually have two windows and an entrance door where one directly enters the canopy and over it into the house. A triangular gable, giebl, usually decoratively embellished, with a wooden fillet, gorge and gully is emphasised, which was the case with the older type of Vojvodina house. The roofs are two sloped and covered by reed. Students paid special attention to decorative embelishments of porch, kong, especially pillars, arches, bolsters, struts and fence. (Fig. 14)

\section{CONCLUSION}

The presented introductory analysis of the development of studies in the field of architecture at the Belgrade College School and later on the Faculty of Technical Sciences, in the period before and after the WWI, demonstrates that the studies of the old national architecture, i.e. mainly monumental and sacral medieval architecture, were gradually introduced and applied in a balanced way in the students' projects of that time through the Byzantine Style course. This was an effort to create a recognisable national style in which the buildings of that time would be designed. A significant change occurred in the 1930s when traditional vernacular architecture gained its significance in the study programme mostly due to Professor Deroko. Vernacular architecture took its rightful position in research and lectures with the establishment of the Institute of Vernacular Architecture and the Department of Vernacular Architecture at the Faculty of Architecture in Belgrade. This continued after the WWII, when new social relations developed, sacral architecture was not predominantly built, and the architecture of the international style became the dominant form of expression. Monumental sacral medieval architecture was still being studied, but it was not applied to students' works, which exclusively followed universal modernism of that time.

This paved the way for Professor Deroko to share with students his rich knowledge gained through long-term field research of vernacular architecture, not only through lectures, but also through work on practical assignments in which theoretical knowledge was transferred to students' projects. Through the work on particular topics related to research and design in the spirit of traditional 
architecture, in the Vernacular Architecture course, it was demonstrated that the students' engagement in these pojects enriched their education and enabled their inclusion in solving numerous problems related to the design in the spirit of traditional architecture. Through imaginatively created forms but respecting the character and tradition of vernacular architecture, students designed various contemporary facilities, such as teachers' houses, schools, rural and urban national committee houses.

The study programme of this course was geared toward the establishment of a critical attitude toward rural and urban architecture in our surroundings, to identification of character, meaning and value of this area, with the purpose of training professionals to design in the spirit of traditional architecture and forming particular national expression of our region to which pre-war folklorism aspired. It could be argued that the realised students' projects in the Vernacular Architecture course demonstrated that engaging students in solving these problems was very useful resulting in inventive and bold ideas, which is obvious from the review of more significant projects given through illustrations in this paper. The idea to adequately present designed buildings in connection with the surroundings, significant values and views, typical of the region of Kosovo and Metohija and central Serbia was particularly promoted.

The thing to be noted is the engagement of Professor Deroko to equally develop the skills of technical and artistic drawing, where he himself was a master, which also can be seen in the accompanying illustrations, especially in segments where layouts and axonometric views of the designed constructions were given. It is important to mention that in this paper, the reviewed students' projects will be published for the first time in professional circles and to a wider domestic and international public, as part of extremely rich documentation kept in the teachers' office for preservation of the architectural heritage at the Faculty of Architecture in Belgrade. In addition to students' drawings and various publications collected by the professor, his stamp for the Vernacular Architecture course is stored with the office.

Unfortunately, since the reform in 1970s, the new course on the Architecture of the Past in Yugoslavia, taught by Professor Slobodan Nenadović, and later by Professor Jovan Nešković, ${ }^{65}$ did not include practical assignment classes, but was delivered ex-cathedra only. Nevertheless, an independent research of monumental or vernacular architecture has been secured for especially gifted students to replace exams, so high quality seminar papers are still being kept in the teachers' office at the Faculty of Architecture of the University of Belgrade. 

by the Ministry of Education and Science of the Republic of Serbia. 1846-1971, neobjavljeni rukopisi [Higher education of architecture in Serbia 1846-1971, unpublished manuscripts] (Beograd: Arhitektonski fakultet, 1996), 30-31, 136.

Deroko constructed airplanes as a young man with his brother Jovan. See: M. Vranić-Ignjatović and D. Milošević eds., Legende Beogradskog univerziteta, Aleksandar Deroko [Legends of the Belgrade University, Aleksandar Deroko]. Catalogue of the exibition (Beograd: Univerzitetska biblioteka, 2004), 19-21.

He joined student battalion in 1914 as one of 1,300 corporals, then university students. He was chosen to undergo pilot training, and he passed the military pilot exam in France in 1915 thus becoming one of the first Serbian pilots. M. Vranić-Ignjatović and D. Milošević eds., Legende Beogradskog univerziteta, Aleksandar Deroko [Legends of the Belgrade University, 21-22.

M. Vranić-Ignjatović and D. Milošević eds., Legende Beogradskog univerziteta, Aleksandar Deroko, 23; S. Bogunović, Arhitektonska encikopedija Beograda, knj. II. [Architectural Encyclopedia of Belgrade, book II] (Beograd: Beogradska knjiga, 2005), 750-757. 
Newspapers Vreme published the news on architectural exams at the University of Belgrade on 12 February, 1926, reporting that out of 10 candidates only four had passed the exam. Deroko got 966 points out of 1,000. See: M. Vranić-Ignjatović and D. Milošević eds., Legende Beogradskog univerziteta, 23-24; S. Bogunović, Arhitektonska encikopedija Beograda, 750-757.

Ibid., 756.

Visokoškolska nastava, 136.

M. Vranić-Ignjatović and D. Milošević eds., Legende Beogradskog univerziteta, 24.

Ibid.

Ibid., 28-30, 32 .

The first two collection of drawings Narodno neimarstvo I i II [Vernacular Architecture I and II] were published in 1939 and 1940, each with 20 sheets as an edition of the Institute of Vernacular Art of the University of Belgrade. Ibid., 40-41.

An architect, archeologist and art historian. As a state scholarship recepient, he finished his studies of architecture in Karlsruhe. See: Visokoškolska nastava, 127-128.

Zoran Manević, "Beogradska arhitektonska škola [Belgrade Architectural School]" in Univerzitet u Beogradu 1838-1988 (Beograd: Univerzitet u Beogradu, 1988), 622-624; Visokoškolska nastava, 19; Bogdan Nestorović, Arhitektura Srbije u XIX veku [Serbian Architecture in the Nineteenth Century] (Beograd: Art Press, 2006); Mirjana Roter-Blagojević, "Nastava arhitekture na visokim i visokoškolskim ustanovama," ["Teaching Architecture at Higher and Higher Educational Institutions"] Godišnjak grada Beograda, XLIV (1997): 142-145; Мирјана Ротер-Благојевић, “Значај Михаила Валтровића и Драгутина С. Милутиновића за развој образовања из области архитектуре и проучавања градитељског наслеђа на Великој школи у Београду,” [“Тhе Importance of Mihailo Valtrović and Dragutin S. Milutinović for Development of Education in the Field of Architecture and Study of Architectural Heritage at the College School in Belgrade"] in Валтровић и Милутиновић, тумачења (Београд: Историјски музеј Србије, Београд, 2008), 28-51.

Visokoškolska nastava, 19.

An engineer in the Ministry of Construction. Studied on Bauacademie in Berlin, in Munich, and at the Polytechnical School in Karlsruhe. See: Visokoškolska nastava, 128-129; Mirjana RoterBlagojević, "Nastava arhitekture na visokim i visokoškolskim ustanovama," 145-146.

Visokoškolska nastava, 19.

Studied as a state scholarship recepient at the Polytechnical School in Berlin. See: Visokoškolska nastava, 129.

Ibid., 19-20, 129.

Ibid., 20.

Ibid., 21.

Ibid.

Ibid., 22-23.

Ibid., 22.

He collected materials on the monasteries in Gračanica, Dečani and Pećka patrijaršija. See: Manević, "Beogradska arhitektonska škola," 623.

Educated at the Faculty of Technical Sciences in Belgrade and at the Polytechnical School in Berlin. He was an architect within the Ministry of Construction and a part-time professor at the Department of Architecture, where he taught Architectural forms and Ornamentation of all styles from 1898. See: Ibid., 23-24, 131. 
Zoran Manević, "Beogradska arhitektonska škola,” 623-624.

Educated at the Faculty of Technical Sciences in Belgrade and the Polytechnical school in Berlin, an architect in the Ministry of Construction. See: Visokoškolska nastava, 19, 132.

Ibid., 24.

Ibid., 28-29.

Bogdan Nestorović, Arhitektura Srbije u XIX veku, 522-536; Aleksandar Kadijević, Jedan vek traženja nacionalnog stila u srpskoj arhitekturi [One Century of Searching for a National Style in Serbian Architecture] (Beograd: Građevinska knjiga, 1997); Aleksandar Ignjatović, Jugoslovenstvo u Arhitekturi 1904-1941 [Yugoslavism in Architecture 1904-1941] (Beograd: Gradjevinska knjiga, 2007).

Petar Popović graduated from the Faculty of Technical Sciences of the Belgrade College School in 1896 and was employed right away at the Department of Architecture in the Ministry of Construction in Belgrade. See: Visokoškolska nastava, 134-135; Zoran Manević, "Beogradska arhitektonska škola," 624.

S. Ćurčić, Architecture of the Balkans, from Diocletian to Süleyman the magnificent (New Haven and London: Yale University Press, 2010), 627-628, 675.

Visokoškolska nastava, 32.

Ibid., 32.

A booklet Projekti studenata arhitekture [Projects of students of architecture] published in 1928 as an edition of Architecture Students' Club with 17 graduate thesis, works and school projects on St. Sava's topic testifies the scope of architectural studies. Along with eminent architects, such as Andrej Papkov and Branko Krstić, there were future historians and conservators, Đurđe Bošković and Ivan Zdravković. See: Zoran Manević, "Beogradska arhitektonska škola,” 625.

Visokoškolska nastava, 33.

With Popović, Deroko constructed a church in the Letnjikovac village near Požarevac. S. Bogunović, Arhitektonska encikopedija Beograda, 752.

Visokoškolska nastava, 136.

He was born in the Imperial Russia, after revolution around 1921 he came to the Kingdom of SCS, Yugoslavia. He graduated from the Faculty of Technical Sciences in Belgrade. See: S. Bogunović, Arhitektonska encikopedija Beograda, 1071-1076.

Visokoškolska nastava, 33-34.

Ibid., 34.

Ibid.

Ibid.

Ibid., 35-38; The seal with the name of the course is preserved in the teachers' office for Architectural Heritage in Serbia of the Faculty of Architecture in Belgrade today.

Kojić graduated in Paris in 1921 and after returning to Belgrade, he got a job at the Architectural Department of the Ministry of Construction. He was appointed a teching fellow in 1932 and as an assistant professor of Design of Corporate, Industrial and Traffic Buildings course in 1937. See: Ibid., 141-142.

Within the newly-formed Technical School which was abolished in 1954. See: Ibid., 42-43.

Ibid., 89.

The conditions with staff appointments were much better at the Department of History of Art and Architecture after 1947 when young teaching fellows Branislav Vulović, Slobodan Nenadović, Anka Stojaković were appointed and who gradually accepted the curriculum and later became long-term teachers of these courses after the departure of their predecessors. See: Ibid., 46, 88-89. 
Ibid., 46.

Ibid., 91-92.

Ibid., 47.

Ibid., 48-49.

Ibid., 49.

Ibid., 49-51.

This data was personally written by Professor Deroko on a picture he gave to the Office and his heirs when he retired.

Visokoškolska nastava, 149. Mirjana Roter-Blagojević, "Slobodan M. Nenadović (1915-2004): In memoriam," Forum+, 49 (09/2004): 138-143.

Visokoškolska nastava, 52, 92.

Ibid., 53-54. Folić, B., "The contribution to the research into the role of Bogdan Bogdanović in the creation of the new school of architecture in Belgrade," SPATIUM International Review, No. 27 (2012): 19-25.

Nadja Kurtovic-Folic, Mirjana Roter-Blagojevic and Renata Jadresin-Milic, "Teaching of Conservation," in Reformae, Reforming Architectural Education in the Cards Countries, Handbook for European Higher Architectural Education Area (Skopje, 2006), 218-223.

Dr Slobodan Nenadović, dr Jovan Nešković, dr Mirko Kovačević, dr Nadja Kurtović-Folić, dr Mirjana Roter-Blagojević and dr Marko Nikolić.

Visokoškolska nastava, 150.

Ibid., 150.

Graduated in 1957, he obtained MSc in 1975 and PhD in 1984, all at the Faculty of Architecture in Belgrade. Since 1957 he had been employed by the Centre for Housing of the Institute for testing of materials of Republic of Serbia, and served as the director of the Institute of Architecture and Urban \& Spatial Planning of Serbia from 1986 through to 1900. See the official site of the Academy of Architecture of Serbia, http://aas.org.rs/canak-mihailo-biografija/, 1.6.2018.

Visokoškolska nastava, 150. See: Mirjana Roter-Blagojević, “Jovan Nešković (1929-2006): In memoriam," Forum+, 51 (09/2006): 104-111. 
Богуновић, Слободан. Архитектонска еничиклопедија Београда, књ.. II. Београд: Београдска књига, 2005.

Дероко, Александар. Народно неимарство I-II, Београд: Српска академија наука и уметности, 1968.

Игњатовић, Александар. Југословенство у архитектури 1904-1941, Београд: Грађевинска књига, 2007.

Јовановић, Зоран. Александар Дероко. Београд: Републички завод за заштиту споменика културе и Друштво конзерватора Србије, 1991.

Кадијевић, Александар. Један век тражења националног стила у српској архитектури (средина XIX - средина XX века). Београд: Грађевинска књига, 1997.

Kurtovic-Folic, Nadja, Mirjana Roter-Blagojevic and Jadresin-Milic, Renata. "Teaching of Conservation." In Reformae, Reforming Architectural Education in the Cards Countries, Handbook for European Higher Architectural Education Area, 218-223. Skopje: 2006.

Маневић, Зоран. “Београдска архитектонска школа.” In Универзитет у Београду 1838-1988. Београд: Универзитет у Београду, 1988.

Mandrapa, Đorđe and Vladimir Parežanin. "Vernacular Architecture in Serbia in the 19th and the first half of the 20th Centuries - Transformation and Disappearance." Serbian Architectural Journal SAJ, No. 1 (2016):1-22.

Несторовић, Богдан. Архитектура Србије у XIX веку, Београд: Арт Прес, 2006.

Ротер-Благојевић, Мирјана. “Настава архитектуре на високим и високошколским установама у Београду током 19. и почетком 20. века, утицај страних и домаћих градитеља.” Годишњак града Београда, 44 (1997): 125-168.

Ротер-Благојевић, Мирјана. “Значај Михаила Валтровића и Драгутина С. Милутиновића за развој образовања из области архитектуре и проучавања градитељског наслеђа на Великој школи у Београду.” In Валтровић и Милутиновић, тумачења, ур. Т. Дамљановић, 28-51. Београд: Историјски музеј Србије, 2008.

Roter-Blagojević, Mirjana. "Slobodan M. Nenadović (1915-2004): In memoriam.” Forum+, No. 49 (09/2004): 138-143.

Roter-Blagojević, Mirjana. "Jovan Nešković (1929-2006): In memoriam.” Forum+, No. 51 (09/2006): 104-111.

Ротер-Благојевић, Мирјана, Милошевић, Гордана и Николић, Марко. „Едукација из области проучавања и заштите градитељског наслеђа на Архитектонском факултету у Београду.“ Гласник ДКС, бр. 32 (2008): 39-43.

Ротер-Благојевић, Мирјана. "Прилог разматрању теме унапређења едукације из области проучавања и очувања градитељског наслеђа у Србији.” Гласник ДКС, бр. 40 (2016): 29-33.

„Високошколска настава архитектуре у Србији 1846-1971“, необјављени рукописи, Београд: Архитектонски факултет, 1996.

Вранић, Марија и Милошевић, Дубравка. “Легенде Београдског универзитета, Александар Дероко 1894-1988.” каталог изложбе. Београд: Универзитетска библиотека, 2004.

Folić, Branislav. "The contribution to the research into the role of Bogdan Bogdanović in the creation of the new school of architecture in Belgrade." Spatium International Review, No. 27 (2012): 19-25.

Ćurčić, Slobodan. Architecture of the Balkans, from Diocletian to Süleyman the magnificent. New Haven and London: Yale University Press, 2010. 
S A J 2019 - 11 - 